\title{
Effect of Camel Variables on Financial Stability: A Dynamic Panel Analysis of Commercial Banks in Kenya
}

\author{
Nathan Wamalwa ${ }^{1 *} \quad$ John Mungai $^{2}(\mathrm{PhD}) \quad$ Daniel Makori $^{2}(\mathrm{PhD})$ \\ 1.Corresponding Author: Accounting and Finance Department, School of Business, Kenyatta University, Nairobi \\ Kenya \\ 2.Lecturers: Accounting and Finance Department, School of Business, Kenyatta University, Nairobi Kenya
}

\begin{abstract}
A stable banking sector is significant in ensuring economic growth as well as sound, efficient and stable financial system. However, the banking sector in Kenya has been considered fragile and this is evident from the increasing trend of non-performing loans, fluctuating deposit trend of some commercial banks and fluctuations of foreign liabilities in commercial banks in Kenya, which is associated with financial stability. Furthermore the collapsing of some commercial banks and some being put under receivership is of great concern to the financial stability of the commercial banks in Kenya. The general objective of the study was to establish the effect of CAMEL variables on financial stability of commercial banks in Kenya. The specific objectives of the study were to determine the effect of operational efficiency, capital adequacy, bank liquidity, profitability and asset quality on financial stability of commercial banks in Kenya. The study was carried out in 17 fragile commercial banks in Kenya between 2011 and 2018. Generalized Method of Moments (GMM) model guided by dynamic panel regression results revealed that operating efficiency had a statistically significant positive effect on financial stability $(\beta=0.3104109, p=0.037)$ of commercial banks in Kenya. The study also established that capital adequacy had a statistically significant negative effect on financial stability $(\beta=-0.1560403, \mathrm{p}=0.050)$ of commercial banks in Kenya. The study further revealed that bank liquidity had a statistically insignificant negative effect on financial stability $(\beta=-0.0073553$, $\mathrm{p}=0.881$ ) of commercial bank in Kenya. In addition, profitability had a statistically significant negative effect on financial stability $(\beta=-0.1064231, p=0.036)$. Finally, the study revealed that asset quality had a statistically significant positive effect on financial stability $(\beta=0.0987029, p=0.032)$. Based on these findings, the study recommends for mergers and acquisition among the fragile commercial banks as per the fragility index, adoption of internal economics of scale, limits on insider loans to be established and credit to borrowers should not exceed $15 \%$ of the capital. This would ensure a sound and vibrant economy towards achieving the Vision 2030 that advocates for well-functioning, efficient and stable financial system.
\end{abstract}

Keywords: Camel Variables, Firm characteristics, Financial Stability, Dynamic Panel Regression.

DOI: $10.7176 /$ RJFA/11-18-10

Publication date:September $30^{\text {th }} 2020$

\subsection{Introduction}

Financial stability of a commercial bank is the backbone of the entire financial system as banks assume a focal role in the economic growth (Hussein, 2010). Commercial banks in Kenya contribute to a larger percentage of the counties' GDP of $43.22 \%$ (Plecher, 2020). In evaluating the financial stability of a commercial bank, special consideration should provide for recognizing exogenous factors and endogenous elements that rely upon the functioning of the bank and to decide the degree of their effect on the state and activities of the commercial banks (Brauers, Ginevicius \& Podviezko, 2014). Exogenous elements include political, social and economic factors while endogenous variables comprise bank's capital adequacy, liquidity, level of profitability, asset quality, management efficiency and the solvency of the bank. These variables are common to all commercial banks and they have a huge effect on the accomplishment of the financial stability state (Dovhal \& Chamara, 2015). Hence, the financial stability of the banking sector needs to be established to ensure steadiness in the financial system.

Due to the recurring financial crisis, this triggered the G10 governors to come up with a methodology that would ensure financial stability around the globe and thus the formation of Camel Model in 1974 in Switzerland at Basel City hence the name Basel Committee. The Basel Committee on Banking Supervision (BCBS) has been on the forefront in ensuring financial stability in all financial institutions globally (Kouser, Aamir, Mehvish, \& Azeem, 2011). The Basel Committee in 1998 further established Basel Capital Accord I to strength the Camel Model. In June 2004, the Basel Capital Accord II was formulated to strengthen Basel I; in 2010, Basel III was formulated to strengthen Basel II, a risk based approach after the global financial crisis of 2007-2009 (Savluk, 2015). The common narrative among the three accords is the emphasis to strengthen the key internal factors within the financial system, all geared towards attaining financial stability of the sector through establishing minimum requirements of the key internal factors that banks should comply with (BCBS, 2012).

The Central Bank of Kenya (CBK) has traditionally adopted the CAMEL model proposed by BCBS and International Monetary Fund (IMF) to all financial institutions globally (Baral, 2005; Olweny \& Shipho, 2011; Kalunda, 2015), whose firm characteristics namely capital adequacy, asset quality, management efficiency, 
earnings/profitability and liquidity are used to determine the financial stability of commercial banks in Kenya. Despite the initiative by the regulator, the banking sector in Kenya has experienced challenging moments that have seen some commercial banks collapse likes Union Bank, Trust Bank, Charter House Bank and Dubai Bank and some put under receivership such as Chase Bank and Imperial Bank (CBK, 2018). In addition NPLs which is a measure of credit risk are on an increasing trend operating above the prudential threshold of 5\%. NPLs were at $6 \%$ in 2014 and 2015, 10\% in 2016, 12\% in 2017, and 13.5\% in 2018 (Cytonn Banking Sector Report, 2018). Deposit fluctuations which is an indication of bank runs were $6 \%$ in 2014, 14.3\% in 2015, 6.4\% in 2016, 11.7\% in 2017, and 9.4\% in 2018 (Liquidity risk) (Cytonn, 2018). Foreign liabilities fluctuations which is a measure of foreign exchange risk were $\$ 54 \mathrm{M}$ in $2014, \$ 36 \mathrm{M}$ in $2015, \$ 46 \mathrm{M}$ in $2016, \$ 68 \mathrm{M}$ in 2017, and $\$ 50 \mathrm{M}$ in 2018 (Bank Supervisory Report, 2018). Credit risk, liquidity risk and foreign exchange risk constitutes to fragility index of commercial banks. It is against this backdrop that the current study investigates the triggers of financial instability among commercial banks in Kenya.

\subsection{Statement of the Problem}

A stable banking sector is significant in ensuring economic growth, sound, efficient and stable financial system (Gathaiya, 2017). The Central Bank of Kenya (CBK) uses CAMEL Model as a gauge to ascertain the financial stability of commercial banks in Kenya (CBK, 2010). However, despite the adopted model, commercial banks in Kenya have experienced turbulent moments that have seen some commercial banks collapse, with some put under receivership (CBK, 2018). In addition the rates of NPLs in Kenya are on an increasing trend which is of concern; the NPLs are operating above the recommended threshold of 5\% (Dayong et al., 2016). The fluctuating deposit trend of some commercial banks in Kenya is a call for concern (Cytonn, 2018). Furthermore, the fluctuation of foreign liabilities in commercial banks is a point of alarm (Bank Supervisory Report, 2017). This signals financial instability amongst commercial banks in Kenya. Thus, the need arises to investigate the effect of CAMEL variables on financial stability of commercial banks in Kenya.

Financial instability of some commercial banks and those put under receivership has been associated with firm characteristics which constitutes the CAMEL variables namely operational efficiency, capital adequacy, bank liquidity, profitability and asset quality (Kalani \& Waweru, 2009; Kandiru et al., 2015). A stable financial institution is attributed to firm characteristics (Ongore \& Kusa, 2013). Hence, this displays an astounding opportunity to comprehend the key variables prompting this recurring phenomenon, with specific reference to the firm characteristics. There exists substantive empirical literature on firm characteristics and financial stability in financial institutions (Dulah, \& Hela, 2017; MohdZaini, Sok-Gee, \& Sallahudin, 2010; Ameni, Chaibi, \& Omri, 2017; Yong, 2016; Akram, Bilal, Asif, \& Ammar, 2013; Muhammad \& Gang, 2016; Gudmundsson et al., 2013; Ochingo \& Muturi, 2018). However, some of these investigations are on studies conducted from other counties, those whose findings may not be applicable to the local banking context due to differences in market integration, market transparency, market size, market efficiency and market liquidity (Hoyer-Ellefsen, 2004) hence the need for the current study.

\subsection{General Objective}

The general objective of the study was to investigate the effect of CAMEL variables on financial stability of commercial banks in Kenya.

\subsubsection{Specific Objectives}

The study sought to achieve the following specific objectives:

(i) To determine the effect of operational efficiency on financial stability of commercial banks in Kenya.

(ii) To establish the effect of capital adequacy on financial stability of commercial banks in Kenya.

(iii) To determine the effect of bank liquidity on financial stability of commercial banks in Kenya.

(iv) To establish the effect of profitability on financial stability of commercial banks in Kenya.

(v) To determine the effect of asset quality on financial stability of commercial banks in Kenya.

\subsection{Research Hypotheses}

The study tested the following null hypotheses:

$\mathrm{H}_{01}$ : Operational efficiency has no significant effect on financial stability of commercial banks in Kenya.

$\mathrm{H}_{02}$ : Capital adequacy has no significant effect on financial stability of commercial banks in Kenya.

$\mathrm{H}_{03}$ : Bank liquidity has no significant effect on financial stability of commercial banks in Kenya.

$\mathrm{H}_{04}$ : Profitability has no significant effect on financial stability of commercial banks in Kenya.

$\mathrm{H}_{05}$ : Asset quality has no significant effect on financial stability of commercial banks in Kenya.

\subsection{Empirical Review}

This section discusses the relevant empirical literature that supports the research problem. This ensures that the study's content is informed by past studies that are related to it. 


\subsection{1: Operating Efficiency and Financial Stability}

Alber (2016) sought to establish banking efficiency and financial stability of the banking sector in the Middle East and North Africa (MENA) countries. Data envelopment analysis (DEA) was used as proxy of banking efficiency and NPLs as proxy of financial stability in the study. The study was carried out in 15 MENA countries between the years 2004 and 2013. The generalized method of moments (GMM) was employed to ascertain the relationship between the study variables. Two-step system GMM was employed as a test for heterogeneity and autocorrelation. This was ascertained to be free of those biases. From the analysis, efficiency had a positive and significant effect on financial stability of MENA counties. However, the study was carried out in MENA counties whose social, legal and technological environments are parallel to those of Kenya.

Helal and Miah (2017) investigated operational efficiency and financial stability of banks in Gulf Cooperative Council (GCC) countries. Data for analysis was sourced from 48 conventional banks and 38 Islamic banks in GCC countries. Ordinary least square (OLS) regression model was employed for data analysis over the period 2004 to 2014. Stochastic Frontier Analysis (SFA) was used as a measure for operational efficiency. Liquid asset to deposit ratio was also applied to assess the strength of a bank in the short-term. The $\mathrm{Z}$ index was employed as a proxy to financial stability. From the outcome, conventional banks were less stable than Islamic banks in GCC countries. Furthermore, operating efficiency had a statistically significant negative effect on financial stability of Islamic banks in GCC. However, the study was conducted in Middle Eastern countries whose political and economic environments are different from those of Kenya.

Mohdzaini et al. (2010) sought to investigate the relationship between operational efficiency and financial stability in Malaysia and Singapore. Greene (1990) proposed SCF model that was used as a measure to operational efficiency while NPLs were used as a measure of bank stability. The study applied tobit simultaneous equation regression model for the analysis between periods 1998 and 2007. From the findings, it was observed that lower operating efficiency increased NPLs. This in turn leads to instability of the banking sector in Malaysia and Singapore. However, this study was conducted in Malaysia and Singapore whose economic environment is better than that of Kenya. The current study further used fragility index as proxy of financial stability.

Fiordelisi, Marques-Ibanez and Molyneux (2010) investigated efficiency and financial stability of the European banking sector. The study used cost to income ratio as proxy to efficiency and NPL ratio as proxy to financial stability. A granger-causality technique was employed to establish the causal relationship between the study variables. Secondary data was employed where panel data was obtained from published financial statements of the European banking sector. The two-step system GMM was used to remedy the endogeneity issues that arise from the causal effect outcomes in the study. From the findings, efficiency had a statistically significant negative effect on financial stability. The current study however, used fragility index as proxy to financial stability since it gives an early warning signal of financial health of an institution.

\subsection{2: Capital Adequacy and Financial Stability}

Oduora, Ngokab and Odongoba (2017) examined capital adequacy and financial stability in Africa. The study was carried out from 167 banks across African countries between 2000 and 2011. NPL ratio was used as proxy of financial stability. From the findings, small banks had a positive and significant effect on financial stability, implying that capital beef up in small banks lead to increase in financial instability in Africa, with exception of big banks. The scope of the study was too wide and the study did not disclose the countries it reviewed. The present study narrowed down to commercial banks in Kenya. It also used fragility index as a proxy of financial stability; it gives an early warning signal of an institution's financial health.

Gudmundsson et al. (2013) conducted a study on capital adequacy and financial stability of commercial banks in Kenya. The study employed panel regression model to ascertain the association between capital adequacy and financial stability of commercial of banks in Kenya. Return on Equity (ROE) was used as a measure of financial stability that was the dependent variable of the study. Secondary data was collected from 36 commercial banks in the periods 2004 to 2011. From the analysis, capital adequacy had a significant positive effect on financial stability of commercial banks in Kenya. The current study focused on the years 2011 to 2018 among 17 commercial banks in Kenya. However, the imposition of the interest rate cap on commercial banks and the introduction of international financial reporting standards (IFRS 9) triggered the current study.

Githinji and Njuguna (2016) examined capital adequacy and financial stability of commercial banks in Kenya. Descriptive design was employed on 43 commercial banks. A questionnaire was their main tool for data gathering. NPL ratio was used as proxy to financial stability. This was a cross-sectional study hence data was collected at one point in time. Qualitative data was collected, hence could be subject to manipulation. The current study, however, was carried out in 17 commercial banks in Kenya for 8 years from 2011 to 2018. The study was both cross-sectional and longitudinal. Secondary data was used for analysis which cannot be easily manipulated (Kerlinger \& Lee, 2000). From the findings, capital adequacy had a significant relationship with financial stability in commercial banks in Kenya. The current study further utilized fragility index as proxy of financial stability.

Dickson and Marobhe (2013) sought to investigate capital adequacy and asset quality position in commercial banks, Tanzania. The study was carried out in 33 commercial banks between 2006 and 2011. Capital adequacy 
was used as an explanatory variable for the study while NPL ratio was used as proxy to asset quality. Panel regression model was employed to ascertain the relationship between the study variables. From the findings, increase in capital ratio had a significant negative effect on NPLs in commercial banks in Tanzania. Nevertheless, the study was carried out in commercial banks in Tanzania whose economic, social and technological environments are different hence the need to undertake the study in commercial banks in Kenya. Furthermore, the present study used the GMM model.

Karugu, Achoki and Kiriri (2018) examined the effect of capital adequacy ratios on financial stability of commercial banks in Kenya. Core capital to total deposits, total capital to total risk weighted assets and core capital to total weighted assets were employed as the explanatory variable while Z-index was utilized as the proxy to financial stability of commercial banks in Kenya. Logistic regression model was employed to examine the association between capital adequacy ratios and Z-index. Secondary data was extracted from the 43 commercial banks financial statements as per the study period 2009 to 2015. From the findings, core capital to deposit ratio had a statistically significant positive effect on $Z$ index of commercial banks in Kenya. The current study, however, employed GMM as the model. Furthermore, the study was conducted in 17 commercial banks in Kenya that came out as fragile based on the fragility index.

\subsubsection{Bank Liquidity and Financial Stability}

Ameni et al. (2017) studied the effect of bank liquidity on bank stability in the MENA region, Saudi Arabia and Tunisia. The study comprised 49 banks operating in the region from 2006 to 2013. Secondary data was obtained from banking annual reports. The GMM model was used to examine the relationship between the study variable and the $\mathrm{Z}$ index as the measure of bank stability. From the analysis, liquidity risk significantly affected the bank stability of MENA region which implies that an increase in liquidity risk contributed to bank instability. The current study, however, used fragility index as measure for financial stability of 17 commercial banks in Kenya.

Muhammad and Gang (2016) assessed the impact of bank liquidity on financial stability of commercial banks in China. The study employed the GMM estimation, fixed and random effect model and pool data techniques for analysis. Data was extracted from 197 listed and unlisted Chinese banks, spanning the period 2005 to 2014. NPL was used as a measure to financial stability. The findings indicated that total liquidity creation by Chinese banks was declining; and NPLs ratio had started to increase following a continuous decline from 2005 to 2012 . The study concluded that decrease in bank liquidity leads to financial instability among Chinese commercial banks. However, the study was conducted in China whose technological, economic and social environments are different from Kenya. Furthermore, fragility index was used as proxy for financial stability.

Ngaira and Miroga (2018) sought to investigate the effect of liquidity on financial stability of 11 listed commercial banks in Kenya. The study employed questionnaires as a tool of data collection. The data was from 356 employees of listed commercial banks in Kenya. Multiple regression model was utilized to support the analysis. The study adopted real bills doctrine of liquidity management theory, financial inclusion theory, Bank lending channel theory and theory of systemic risk and design of prudential bank regulation. From the findings liquidity had a significant positive effect on financial stability of listed commercial banks in Kenya. However, the current study was conducted on 17 fragile commercial banks in Kenya from 2011 to 2018. The study further employed dynamic panel regression model for the analysis. The current latter study employed secondary data unlike the former study whose data is subject to manipulations.

\subsection{4: Profitability and Financial Stability}

Yong (2016) examined the relationship between profitability and stability of commercial banks in China. The study employed causal research design to ascertain the effect of profitability on stability of Indian commercial banks, applying the GMM model. The secondary data was drawn from 83 city commercial banks, five state-owned commercial banks and 12 joint-stock commercial banks from 2003 to 2013 . ROA was employed as a measure of profitability while Z-index was used as proxy to stability. From the analysis, there is a negative relationship between profitability and stability of commercial banks in China which implies that the higher the profits, the lower the stability. This study focused on the effect of profitability on financial stability of commercial banks in Kenya for the period between 2011 and 2018; and the profit margin was used as proxy of profitability.

Ali and Chin (2018) sought to explore bank profitability and stability of commercial banks in Pakistan. The study used internal determinants of bank profitability such as bank size, liquidity risk, credit risk and funding risk explanatory variables. The study was carried out in 24 commercial banks from 2007 to 2015. Panel regression model was employed to aid inferential statistics based on balanced panel data. From the findings, liquidity risk, bank size and funding risk had statistically significant effect on stability. Credit risk had an insignificant effect on financial stability. However, the study was carried out in Pakistan which is economically and socially different from Kenya. Furthermore, the GMM model was in the current study.

Albulescuab (2015) studied bank profitability and financial soundness indicators of the banking sector in emerging countries located in Central and South America. Liquidity, bank capitalization, interest rate margins, non-interest expense and NPLs were used as proxies to financial soundness indicators of the study. ROE and ROA were used as proxies of profitability. Data from six countries namely Chile, Colombia, Elsalvador, Honduras, 
Mexico and Paraguay for the study period between 2006 and 2013 were sought. From the findings, liquidity, interest rate margins and bank capitalization had a positive and significant effect on profitability while non-interest expense and NPLs had a significant negative effect on profitability. The study, however, was conducted in emerging markets whose market size and market transparency is different from developing countries such as Kenya.

Das, TengTeng and $\mathrm{Hu}$ (2019) sought to examine the impact of profitability on financial stability of 431 publicly traded banks in Europe and Global Systemically important banks (GSIBS). The study employed return on average asset (ROAA), return on average equity (ROAE), risk adjusted ROAA, risk adjusted ROAE, and price to book ratio as proxies to profitability. Systemic risk and idiosyncratic risk measures were proxy to financial stability. The study used GMM model utilized guided by dynamic panel regression to ascertain the impact of profitability on financial stability of Europe banks and GSIBS. The study was carried out between 2004 and 2017 with a sample study of 432 publicly traded banks of Europe and GSIBS. From the findings the study found out that profitability had a statistically significant negative effect on financial stability of banks in Europe and GSIBS as measured by both systemic risk and its idiosyncratic risk.

\subsubsection{Asset Quality and Financial Stability}

Sopan and Dutta (2018) sought to determine the effect of asset quality on liquidity risk of banks in India. The study employed panel data to ascertain the relationship between asset quality and liquidity risk of Indian banks. NPLs to total advances were employed as the proxy to asset quality while liquid asset to total asset ratio was employed as proxy to liquidity risk of Indian banks. Data was extracted from 45 Indian banks comprising state Bank of India group banks that were used for the analysis. From the findings, asset quality had a statistically significant negative effect on liquidity risk of Indian banks. The current study, however, looked at asset quality measured by loss loan provision to operating income as the explanatory variable and fragility index as proxy to financial stability as the dependent variable. GMM model was also employed in the study. The study was carried out among commercial banks in Kenya.

Lucky and Nwosi (2015) sought to determine asset quality and performance of commercial banks in Nigeria. Multiple regression model was employed to ascertain the relationship between asset quality and performance of commercial banks in Nigeria. Secondary data was extracted from listed commercial banks in Nigeria. Nigeria Stock Exchange platform was utilized for data collection. Profitability ratio was used as measure of banks' performance while loan loss provision to total asset ratio and loan loss provision to total loans ratio were employed as proxy to asset quality. From the findings, both loan loss provision to total asset and loan loss provision to total loan had a statistically insignificant negative effect on profitability ratio. However, the current study looked at asset quality which was proxied by loan loss provision to operating income ratio while fragility index was employed as proxy of financial stability. Furthermore, GMM model was employed for the study.

Syajarul, Mohd and Shifa (2018) sought to investigate the effect of asset quality on liquidity risk in the banking sector from the sixteen selected Organizations of Islamic Countries (OIC). The study employed loan loss reserve to gross loans as proxy to asset quality while net loan to deposit ratio was used as proxy of liquidity risk in the study. Fixed effect model was utilized to examine the liquidity risk determinants. The data was extracted from the World Development Indicator (WDI) World Bank and the data from the level banks between years 1999 and 2013. From the findings, the study established that asset quality had a statistically significant negative effect on liquidity risk of OICs. The current study, however, employed loan loss provision to operating income ratio as proxy to asset quality while fragility index was employed as a measure of financial stability in commercial banks in Kenya.

\section{Research Methodology \\ 3.1 Empirical Model}

In order to investigate the effect of firm characteristics (Camel Variables) on financial stability of commercial banks in Kenya, the study adopted two-step system generalized method of moment GMM model, whose proponents are Arellano and Bover (1995), and applied by Mariusz and Katarzyna (2015), Gulzara (2018) as shown in Equation 3.5. The study was guided by dynamic panel regression model. The advantage with dynamic paneldata approach is that the left-hand side indicator is singular (Roodman, 2009). This is unlike probit, tobit and logistic model that require the left hand side indicator to be binary or multinomial (Field, 2009). Another unique merit of dynamic panel-data model is that it gives the fundamental stage to represent past behaviour impact straightforwardly on current behaviour, while perceiving the way that individual cross-sectional units have a preference to carry on in a specific manner (Adenutsi, 2014). GMM model was deemed suitable model for this study since it took care of endogenity problems and unobserved heterogeneity (Trujillo, 2013).

The dynamic panel regression model is given by: $y i \mathrm{t}=\beta 0+\beta \mathrm{i} y i_{\mathrm{t}-1}+\beta \mathrm{i}$ xi $t+u i+\varepsilon i \mathrm{t}$

Here, the dependent variable $y i t$ is the proxy of financial stability for banks $i$ in period $t ; y i_{\mathrm{t}-1}$ is the lagged dependent variable; $\mathrm{x}_{\text {it }}$ represents explanatory variables (firm characteristics); $u i$ is the unobserved subject while 
$\varepsilon i t$ is the disturbance term. The empirical approach was based on system generalized method of moments GMM estimators that properly account for endogeneity bias (Blundell \& Bond, 1998).

Equation (1) was further expanded to obtain Equation (2) whereby yit was substituted with fragility index as proxy to financial stability while the xit was substituted with explanatory variables.

$\mathrm{FI}$ it $=\beta 0+\beta \mathrm{i} \mathrm{FI} i_{t-1}+\beta 1 \mathrm{OPE}$ it $+\beta 2 \mathrm{CPA}$ it $+\beta 3 \mathrm{BLQ}$ it $+\beta 4 \mathrm{PRT}$ it $+\beta 5 \mathrm{ASQ}$ it $+u i+$ cit .......

Where:

FI $i t=$ Fragility Index of commercial bank $i$ at time $t$; OPEit $=$ Operational Efficiency of commercial bank $i$ at time $t$; CPAit $=$ Capital Adequacy of commercial bank $i$ at time $t$; BLQit $=$ Bank Liquidity of commercial bank $i$ at time $t$; PRT $i t=$ Profitability of commercial bank $i$ at time $t$; ASQit $=$ Asset Quality of commercial bank $\mathrm{i}$ at time $\mathrm{t} ; \beta 0=$ Constant term; $y i_{\mathrm{t}-1}=$ Lagged dependent variable; $\beta \mathrm{s}=$ Coefficients of explanatory variables; $u i=$ unobserved time invariant; $\varepsilon i t=$ Disturbance term; Subscript $i=$ Commercial banks (Cross - section dimension) ranging from 1 to 17; and subscript $t=$ Years (time - series dimension) ranging from 2011 to 2018.

Table 1: Operationalization and Measurement of Study Variables

\begin{tabular}{|l|l|l|c|}
\hline Category & Variable & Operationalization & Measurement \\
\hline Dependent Variable & Financial Stability & Fragility Index & (See Equation 3) \\
\hline \multirow{5}{*}{$\begin{array}{l}\text { Independent } \\
\text { Variable }\end{array}$} & $\begin{array}{l}\text { Operational } \\
\text { Efficiency }\end{array}$ & Operational Efficiency Ratio & $\frac{\text { Cost }}{\text { Income }}$ \\
\cline { 2 - 4 } & Capital Adequacy & Capital Adequacy Ratio & $\frac{\text { Core Capital }}{\text { Total Deposit }}$ \\
\cline { 2 - 4 } & Bank Liquidity & Bank Liquidity Ratio & $\frac{\text { Total Loan }}{\text { Customer Deposit }}$ \\
\cline { 2 - 4 } & Profitability & Profitability Ratio & $\frac{\text { Profit Before Tax }}{\text { Total Assets }}$ \\
\cline { 2 - 4 } & Asset Quality & Asset Quality Ratio & $\frac{\text { Loan Provision }}{\text { Operating Income }}$ \\
\hline
\end{tabular}

Source: Researcher (2019)

$\mathrm{FI}_{\mathrm{it}}=\frac{\frac{(\mathrm{r} \mathrm{NPL}-\mu \mathrm{NPL}}{\delta \mathrm{NPL}}+\frac{\mathrm{rDEP}-\mu \mathrm{DEP}}{\delta \mathrm{DEP}}+\frac{\mathrm{rFL}-\mu \mathrm{FL}}{\delta \mathrm{FL}}}{3}$

Where:

FI it $=$ Fragility Index of a commercial bank $i$ at time $t, \mu=$ Arithmetic Mean/Min of NPL, DEP and FL of the banking sector, ${ }^{\delta}=$ Standard Deviation of SC, DEP, and FL of the banking sector, $r=$ Real Value of NPL, DEP and FL of a commercial bank $i$ at time $t \mathrm{NPL}=$ Non Performing Loan of a commercial bank $i$ at time $t$ DEP $=$ Banking Sector Deposits of a commercial bank $i$ at time $t$.

A fragility index of a mean of 0 up to 0.5 signifies a healthy banking sector; any deviations from the threshold and above 0.5 indicate risk-taking activities by an individual commercial bank which is termed as fragile stage (Loloh, 2014: Ahmad and Mazlan, 2015). Fragile commercial banks do not necessarily imply that an individual commercial bank is collapsing; rather, it signals how vulnerable the banking system is to systematic risk (Kibritcioglu, 2002).

\section{Results and Discussions}

\subsection{Descriptive Statistics}

Table 2: Descriptive Statistics for the Data Used in the Analysis

\begin{tabular}{lccccc}
\hline Variable & Observations & Mean & Std. Dev. & Min & Max \\
\hline Fragility Index & 136 & 1.211765 & 0.8961695 & 0.2 & 4.2 \\
Operating Efficiency & 136 & 0.6495869 & 0.3801746 & 0.2291031 & 3.244755 \\
Capital Adequacy & 136 & 0.1806939 & 0.0435236 & 0.0210838 & 0.2888626 \\
Bank Liquidity & 136 & 0.7552303 & 0.2675307 & 0.1518293 & 1.427561 \\
Profitability & 136 & 0.0344108 & 0.0247068 & -0.0613063 & 0.0988981 \\
Asset Quality & 136 & 0.2470032 & 0.2536721 & 0.0204832 & 1.70049 \\
\hline
\end{tabular}

\section{Source: Researcher (2019)}

Results in Table 2 indicate that the mean value of fragility index is 1.211765 with a standard deviation of 0.8961695 , a minimum value of 0.2 and a maximum value of 4.2 respectively. A fragility index of 1.211765 implies that the commercial banks under study were fragile since the value 1.2 is above the threshold of 0.5 . A minimum value of 0.2 implies that some of the commercial banks under study were operating at a stable state before transiting to fragility state over the study period. The maximum value of 4.2 shows how far some of the commercial banks deviated from the threshold of 0.5 . The higher the fragility index, the risky the commercial bank 
is to a financial crisis.

From the findings, the mean value of operating efficiency is 0.6495869 . This indicates that on average, most of the commercial banks have their costs more than incomes. The recommended threshold of operating efficiency is 0.5 and below (Cytonn, 2019), efficiency above 0.5 exposes a bank to a fragile state. Table 2 shows that capital adequacy had a mean of 0.1806939 with a standard deviation of 0.0435236 , and minimum and maximum values of 0.0210838 and 0.2888626 respectively. The minimum value of 0.0210838 indicates that some of the commercial banks were operating below the required capital base, thus making them risky commercial banks to customer clientele. Table 2 indicates that the mean value of bank liquidity is 0.7552303 with a standard deviation of 0.7552303 , and minimum and maximum values as 0.1518293 and 1.427561 respectively. The minimum value indicates that some commercial banks were having liquidity problems during the study period, since they were operating below the recommended threshold of $20 \%$ and below (Cytonn, 2019).

Table 2 further indicates the mean value of profitability as 0.0344108 with a standard deviation of 0.0247068 and minimum and maximum values of -0.0613063 and 0.0988981 respectively. The minimum value of -0.0613063 indicates that many commercial banks have been reporting negative profits at the end of the financial year during the study period. In this way, they are made vulnerable to healthy competition in the market. The mean asset quality as indicated in Table 2 shows a value of 0.2470032 with a standard deviation of 0.2536721 and minimum and maximum values as 0.0204832 and 1.70049 respectively. The mean value of 0.2470032 implies that banks have been experiencing high bad loans, making them create provisions for bad debts, defaults on loan places a bank in fragile state.

\subsection{Diagnostic Tests}

This segment presents the outcomes of the following diagnostic tests: Multicollinearity test normality test, autocorrelation test, heteroscedasticity test, panel unit root, and model specification test which comprise fixed and random effect models.

\subsubsection{Multicollinearity}

The study with the help of regression model was able to obtain variance inflation factors (VIF) and tolerance for use in ascertaining whether multicollinearity would pose a problem in analysis. The independent variables with VIF of less than 10 and a tolerance value greater than 0.1 are recommendable for ruling out the possibility of multicollinearity (Myers, 1990). The results for test of multi-collinearity are as shown in Table 3.

Table 3: Multicollinearity Test Results

\begin{tabular}{|l|c|c|l|}
\hline \multicolumn{3}{|c|}{ Coefficients } \\
\hline & Tolerance & VIF & Remarks \\
\hline Operating Efficiency & 0.523260 & 1.91 & Absence of Severe Multicollinearity \\
Capital Adequacy & 0.779683 & 1.28 & Absence of Severe Multicollinearity \\
Bank Liquidity & 0.788908 & 1.27 & Absence of Severe Multicollinearity \\
Profitability & 0.452978 & 2.21 & Absence of Severe Multicollinearity \\
Asset Quality & 0.570446 & 1.75 & Absence of Severe Multicollinearity \\
\cline { 3 - 4 } & & Mean VIF 1.65 & Absence of Severe Multicollinearity \\
\hline
\end{tabular}

\section{Source: Researcher (2019)}

Table 3 documents the VIF for operating efficiency (VIF=1.91), capital adequacy (VIF=1.28), bank liquidity (1.27), profitability (2.21) and asset quality (1.75) mean VIF was 1.65. VIFs for all the independent variables are less than $3(\mathrm{VIF} \leq 3)$ indicates no multicollinearity. VIFs of $\geq 3$ indicate collinearity and more than 10 indicated a problem with multi-collinearity (Myers, 1990). The outcome, thus inferred as non-presence of a multicollinearity issue among the variables and henceforth the degree of multicollinearity in the model, could be endured.

\subsubsection{Test for Normality}

The study utilized Jarque-Bera test to see whether the variables were normally distributed or not.

Table 4: Normality Test Results

\begin{tabular}{|l|l|l|l|l|l|}
\hline \multicolumn{6}{|l|}{ Skewness/ Kurtosis tests for Normality } \\
\hline Variable & Observations & Pr (Skewness) & Pr (Kurosis) & Adj chi2 & Prob $>$ chi2 \\
\hline My Residuals & 109 & 0.0898 & 0.2152 & 4.50 & 0.1051 \\
\hline
\end{tabular}

Source: Researcher (2019)

From the outcome in Table 4, the study utilized Jarque-Bera test as test of normality. The null hypothesis under this test was that the residuals were not significantly different from a normal distribution. Given that the pvalue is more than 0.05 significant level for the residual, the null hypothesis was not rejected, hence the conclusion that the residuals were normally distributed.

\subsubsection{Test for Autocorrelation}

The study employed Arrelano and Bond (1991) autocorrelation test that was suitable for dynamic panel model. The phenomenon of autocorrelation is the case where successive residuals appear to be correlated with each other. The model recommends for the AR (1), first order autocorrelation and the AR (2), second order autocorrelation. 
The null hypothesis is that there is no serial correlation in either first order autocorrelation or second order autocorrelation.

Table 5: Autocorrelation Test for Fragility Index

Arellano Bond test for zero Autocorrelation in fist differenced errors

\begin{tabular}{|l|lc|}
\hline Order & Z & \\
& Prob $>$ Z & \\
\hline 1 & -1.5645 & 0.1177 \\
2 & 0.04859 & 0.9612 \\
\hline
\end{tabular}

$\mathrm{H}_{0:}$ no autocorrelation

Source: Researcher (2019)

The output in Table 5 presents no significant evidence of serial correlation in the first-differenced errors at order 1 and at order 2 . Thus, the null hypothesis of no serial correlation is evident and the study concluded that residuals were not serially correlated

\subsubsection{Heteroscedasticity Test}

Heteroscedasticity is a regression issue that is normal with cross-section information, where there are expansive contrasts in measure between perceptions. It shows itself by methods for the error term that does not have a steady difference. The researcher used Breuch Pagan test to detect the problem of heteroscedasticity in the model.

Table 6: Heteroscedasticity Test Results

Breusch - Pagan / Cook-Weisberg test for heteroscedasticity

H0: Constant variance

Variables: Fitted values of fragility Index

Chi2 $(1)=2.61$

Prob $>$ chi $2=0.1065$

\section{Source: Researcher (2019)}

As shown in Table 6, the study tested for heteroscedasticity, utilizing Breusch-Pagan test. The null hypothesis was that the error term was homoscedastic. The calculated $p$ value for variables fitted values of fragility index 0.1065 which is more than the critical value 0.05 , implying that the error terms were homoscedastic.

4.4.5 Panel Unit Root Tests

This study utilized hadri Lagrange Multiplier (LM) test; null hypothesis is that panel as a unit root. The study employed hadri LM test since it takes care of missing data unlike other panel roots that cannot execute the data with missing information. Table 7 presents the panel unit root test at level difference.

Table 7: Panel Unit Root Test

\begin{tabular}{lccc}
\hline Variable & Test & $\begin{array}{c}\text { At Level difference } \\
\text { Statistics }\end{array}$ & Significance \\
\hline Fragility Index & Hadri LM Test Z & 12.6943 & 0.0000 \\
Operating Efficiency & Hadri LM test Z & 3.8444 & 0.0001 \\
Capital Adequacy & Hadri LM test Z & 8.6547 & 0.0000 \\
Bank Liquidity & Hadri LM test Z & 6.8268 & 0.0000 \\
Profitability & Hadri LM test Z & 3.2405 & 0.0006 \\
Asset Quality & Hadri LM test Z & 10.9923 & 0.0000
\end{tabular}

\section{Source: Researcher (2019)}

As reported in Table 7 the hadri LM test presented $p$-values that are less than 0.05 . These finding had to reject the null hypothesis that all panel have unit root for fragility index, operating efficiency, capital adequacy, bank liquidity, profitability and asset quality. The study in this scenario reached a consensus that all the variables under study did not have unit root; they were in that case used at that level instead of their first difference. This means that the outcome extracted was not misleading (Gujarati, 2003).

\subsubsection{Model Specification Test}

Baltagi (2005) eludes that for a researcher to conclude whether to employ fixed effect model or random effect model on the panel data, model specification test is significant. Table 8 displays the model specification test for fragility index, showing whether to apply fixed or random effect model in the analysis. 
Table 8: Model Specification Test for Fragility Index

\begin{tabular}{|c|c|c|c|c|}
\hline \multicolumn{5}{|c|}{ Coefficients } \\
\hline & (b) & (B) & (b-B) & $\operatorname{Sqrt}(\operatorname{diag}(\mathbf{v}$ b-v_v_B $)$ \\
\hline & fe & re & Differences & S.E \\
\hline Operating Efficiency & .1318926 & .2512869 & -.1193944 & .2259843 \\
\hline Capital Adequacy & -.1825975 & -.1818691 & -.0007284 & .0398839 \\
\hline Bank Liquidity & -.1131818 & -.0479555 & -.0652263 & .043929 \\
\hline Profitability & .1883397 & .2932805 & -.1049409 & .0521985 \\
\hline Asset Quality & .3413771 & .3248076 & .0165695 & .0282881 \\
\hline \multicolumn{5}{|c|}{$\begin{array}{l}\mathrm{b}=\text { consistent under } \mathrm{H}_{0} \text { and } \mathrm{H}_{\mathrm{a}} \text {; obtained from xtreg } \\
\mathrm{B}=\text { inconsistent under } \mathrm{H}_{\mathrm{a}} \text {, efficient under } \mathrm{H}_{0} \text {; obtained from xtreg } \\
\text { Test: } \mathrm{H}_{0}: \text { difference in coefficients not systematic } \\
\text { Chi2 }(4)=(\mathrm{b}-\mathrm{B})^{\prime}\left[\left(\mathrm{v} \_\mathrm{b}-\mathrm{v}_{-} \mathrm{B}\right)^{\wedge}(-1)\right](\mathrm{b}-\mathrm{B})=9.70 \\
\text { Prob }>\text { chi2 }=0.1380 \\
(\mathrm{~V} \text { b-V_B is not positive definite })\end{array}$} \\
\hline
\end{tabular}

\section{Source: Researcher (2019)}

From the output obtained in Table 8, the null hypothesis is that random effects model is appropriate; the alternative hypothesis is that fixed effects model is appropriate under model specification test. If $P$ value is greater than the critical value 0.05 , the null hypothesis is not rejected. In this finding, the $P$ value was greater than the critical value with ( $\mathrm{p}$-value $=0.1380>0.05)$. The random effect model was therefore appropriate for the model as suggested by Green (2008).

\subsection{Test of Hypothesis}

Table 9: Dynamic Panel Regression Results Based on Fragility Index

\begin{tabular}{|lcccc|}
\hline Fragility Index & Coef. & Std. Err & $\mathbf{z}$ & $\mathbf{P}>|\mathbf{z}|$ \\
\hline Fragility Index & $0.7688454^{*}$ & 0.1177298 & 6.53 & 0.000 \\
L1. & & & & \\
Operating Efficiency & $0.3104109^{*}$ & 0.1491036 & 2.08 & 0.037 \\
Capital Adequacy & $-0.1560403^{*}$ & 0.0796032 & -1.96 & 0.050 \\
Bank Liquidity & -0.0073553 & 0.0490955 & -0.15 & 0.881 \\
Profitability & $-0.1064231^{*}$ & 0.0508232 & -2.09 & 0.036 \\
Asset Quality & $0.0987029^{*}$ & 0.0459348 & 2.15 & 0.032 \\
cons & -0.0504875 & 0.3295215 & -0.15 & 0.878 \\
\hline Wald chi2(6) $=147.55$ & Prob $>$ chi2 $=0.0000 \quad \boldsymbol{( *}^{*}$ ) denote 5\% level of significance & \\
\hline
\end{tabular}

\section{Source: Researcher (2019)}

As per the outcome in Table 9 the following model was extracted:

$F I_{\text {it }}=-0.0504875+0.7688454 \mathrm{FI}_{i t-1}+0.31041090 P E$ it $-0.1560403 C P A_{i t}-0.0073553 B L Q_{\text {it }}-0.1064231 P R T_{\text {it }}$ $+0.0987029 A_{S Q} Q_{i t}+\varepsilon$. 3.6

Where:

$\mathbf{F I}$ it $=$ Fragility index at commercial bank $i$ and time $t ; \mathbf{F I}_{i \mathbf{t}-\mathbf{1}}=$ Lagged fragility index at commercial bank $i$ and time $t$ OPE $_{\mathbf{i} \mathbf{t}}=$ Operational Efficiency of commercial bank $i$ at time $t ; \mathbf{C P A}_{\mathbf{i t}}=$ Capital Adequacy of commercial bank $i$ at time $t$; $\mathbf{B L Q}_{i t}=$ Bank Liquidity of commercial bank $i$ at time $t$; $\mathbf{P R T}_{i t}=$ Profitability of commercial bank $i$ at time $t ; \mathbf{A S Q}_{i t}=$ Asset Quality of commercial bank $i$ at time $t$.

The outcome in Table 9 shows that Wald Chi square is highly significant $(\mathrm{P}=0.000<0.05)$. This suggests that jointly fragility index lag 1, operating efficiency, capital adequacy, bank liquidity, profitability and asset quality determined financial stability as measured by fragility index. From the findings, the fragility index lag 1 had a significant $p$ value of less than $0.05(0.000<0.05)$. It implies that the previous year's fragility index had an accrue effect on current year's fragility index as per the sample.

\section{Ho1: Operating efficiency has no significant effect on financial stability of commercial banks in Kenya}

The first specific objective of the study sought to determine the effect of operating efficiency on financial stability of commercial banks in Kenya. The outcomes are as presented in Table 9. To meet this objective, a null hypothesis, $\mathbf{H}_{01}$ that operating efficiency has no significant effect on financial stability of commercial banks in Kenya was developed. In Table 9, the coefficient of cost to income ratio (operating efficiency) $(\beta=0.3104109, p=0.037<0.05$ ) indicates that operating efficiency has a statistically significant positive effect on financial stability as measured by fragility index. In this case, the null hypothesis that operating efficiency has no significant effect on financial stability of commercial banks in Kenya was rejected at 5\% level of significance. This implies that there is a 5\% chance that the outcome streams from a random distribution. It signifies that there is a $95 \%$ probability that operating efficiency has a technically statistically significant positive effect on financial stability of commercial 
banks in Kenya. This is because the $p$ value is less than 0.05 , indicating that the coefficient obtained is different from zero, thus the rejection of the null hypothesis in the study.

The positive coefficient of 0.31041090 in the finding indicates that a unit increase in operating efficiency holding other variable constant would lead to a 0.3104109 increase in fragility index hence financial instability as per the outcome. The positive sign obtained in this study agrees with Efficiency Structure Theory. Briefly, the Efficiency Structure Theory states that low cost to income ratio would lead to a stable firm; a higher ratio of operating efficiency would imply unstable commercial bank. The result corroborates with those of Alber (2016) and Helal and Miah (2017). However, the findings were inconsistent with those of Fiordelisi, Marques-Ibanez and Molyneux (2010). The inconsistency could be due to differences in contextual aspects. Kenya is operating on a frontier market; the latter study was carried out in a developed country.

\section{Ho2: Capital Adequacy has no significant effect on financial stability of commercial banks in Kenya}

The second specific objective of the study sought to establish the effect of capital adequacy on financial stability of commercial banks in Kenya. The finding summarizing this analysis is in Table 9. To meet this objective, the researcher developed a null hypothesis, $\mathbf{H}_{02}$ that capital adequacy has no significant effect on financial stability of commercial banks in Kenya. In Table 9, the coefficient of core capital to deposit ratio (capital adequacy) $(\beta=-$ $0.1560403, p=0.050<0.05)$ indicates that capital adequacy has a statistically significant negative effect on financial stability as measured by fragility index. In this case, the null hypothesis that capital adequacy has no significant effect on financial stability of commercial banks in Kenya was rejected at 5\% level of significance.

The negative coefficient of -0.1560403 in the outcome indicates that a unit increase in capital adequacy, holding other variables constant, would lead to a 0.1560403 decrease in fragility index hence financial stability. Nevertheless, a unit decrease in core capital to deposit ratio (capital adequacy) would lead to an increase in fragility index hence financial instability as a result of bank runs that emerge from the customer deposits. The findings further approve the necessities by Basel III guidelines on the utilization of the capital adequacy proportion to foresee and monitor the financial stability of the banking sector. The finding furthermore concurs with Buffer Capital Theory. In a nutshell the theory states that the more capital a commercial bank has the more stable it is. The results were also consistent with those of Gudmundsson et al. (2013), Githinji and Njuguna (2016), Oduora, Ngokab and Odongoba (2017). However, the findings were inconsistent with those of Dickson and Marobhe (2013), Karugu, Achoki and Kiriri (2018). The inconsistency in the former study could be due to differences in markets while the latter could be due to contextual differences. The latter study by Karugu et al. was carried out in 43 commercial banks in Kenya; the current study was carried out among the 17 fragile commercial banks in Kenya.

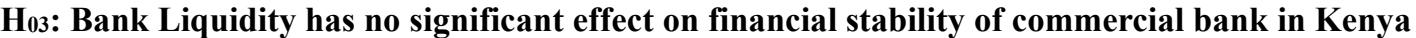

The third specific objective of the study sought to determine the effect of bank liquidity on financial stability of commercial banks in Kenya. A null hypothesis $\left(\mathbf{H}_{\mathbf{0 3}}\right)$ that bank liquidity has no significant effect on financial stability of commercial banks in Kenya was developed to achieve this objective. Table 9 on the coefficient of bank liquidity measure by total loan to deposit ratio $(\beta=-0.0073553, p=0.881>0.05)$ shows that bank liquidity has statistically insignificant negative effect on financial stability as measured by fragility index. Therefore, the null hypothesis that bank liquidity has no significant effect on financial stability of commercial banks in Kenya was not rejected at $5 \%$ level of significance. This implies that bank liquidity coefficient is not different from zero since the $p$ value is not less than 0.05 .

The negative coefficient of bank liquidity of -0.0073553 indicates that a unit increase in loan to deposit ratio (bank liquidity) holding other variables constant would lead to a decrease in fragility index in the same direction and magnitude hence financial stability. This implies an increase in loan disbursement by commercial banks to loyal customers, the more stable the industry becomes due to monies earned from such activities. However, the effect was not significant. This implies that increase in loan disbursement does not guarantee stability due to defaults rate that occasionally accrue from such activities. The finding corroborates with that of Muhammad and Gang (2016).

\section{H04: Profitability has no significant effect on financial stability of commercial banks in Kenya}

The fourth objective sought to establish the effect of profitability on financial stability of commercial banks in Kenya. The study developed a null hypothesis to achieve this objective, $\mathbf{H}_{04}$, that profitability has no significant effect on financial stability of commercial banks in Kenya. In Table 9, the coefficient of profitability proxy by profit before tax over total asset ratio $(\beta=-0.10642319, p=0.036<0.05)$ shows that profitability has statistically significant negative effect on financial stability as measured by fragility index. Therefore, the null hypothesis that profitability has no significant effect on financial stability of commercial banks in Kenya was rejected at 5\% level of significance.

The negative coefficient of -0.10642319 in the outcome reveals that a unit increase in profitability holding other variables constant leads to -0.10642319 decrease in fragility index hence financial stability of commercial banks in Kenya. The finding implies that commercial banks reporting negative profit before tax at the end of the financial year, in a great way affects the stability of the institution negatively. From the analysis, the study found 
out that some commercial banks were reporting negative profits. This places not only those individual banks to the risk of collapse but rather the stability of the industry at jeopardy. Shareholders of negative reporting commercial banks would not be able to get returns from their investment, hence conflicts between the shareholders and the managers will emerges. In this way, the Agency Theory comes into play. When one bank collapses, the other banks are also affected through the risk of contagion because of the interconnection among commercial banks. This finding corroborates with that of Yong (2016).

\section{$H_{05}$ : Asset Quality has no significant effect on financial stability of commercial bank in Kenya}

The fifth specific objective of the study sought to establish the effect of asset quality on financial stability of commercial banks in Kenya. The study formulated a null hypothesis to achieve this objective, $\mathbf{H}_{\mathbf{0 5}}$, that asset quality has no significant effect on financial stability of commercial banks in Kenya. In Table 9, the coefficient of asset quality measured by loan loss provision to operating income $(\beta=0.0987029, \mathrm{p}=0.032<0.05)$ indicates that asset quality has statistically significant positive effect on financial stability as measured by fragility index. In this case, the null hypothesis that asset quality has no significant effect on financial stability of commercial banks in Kenya was rejected at $5 \%$ at level of significance. This implies that there is a $5 \%$ chance that the outcome has come from a random distribution.

The positive coefficient of 0.0987029 in the outcome reveals that a unit increase in asset quality, holding other variables constant, would lead to 0.0987029 increase in fragility index hence financial instability. The finding, therefore, implies that an increase in loan loss provision is a clear indication the bad loans are being experienced within the industry which is a stake to the stability of commercial bank. This further implies that the operating incomes are being consumed by the loan loss provision created. The findings concur with the Information Asymmetry Theory. The theory brings about the idea of insufficient information that the lender receives from the borrowers, thus bad loans being experienced as a result of information asymmetry. However, the finding is inconsistent with those of Lucky and Nwosi, (2015), Sopan and Dutta (2018) who found out a negative effect on bank performance.

\subsection{Conclusions and Recommendations}

Based on the findings, the study concluded that commercial banks in Kenya should ensure that the Camel variables requirements are implemented to the later. This will help in ensuring that commercial banks in Kenya are stable since Camel variables have a significant effect of financial stability of commercial banks in Kenya. The study further concluded that increase in non-performing loans among commercial banks is a threat to financial stability of commercial banks. The study furthermore concludes that bank run is a signal for future financial difficulties that commercial banks will encounter and thus they risk collapse if measures are not instituted to cap the bank runs.

Based on the findings the following further recommendations were made to the commercial banks. First the study recommends that commercial banks of Kenya should embrace advanced digitalization that will ensures smooth and efficient running of bank activities, and in so doing they should shorten customer engagement through simplified process. Secondly the study recommends that commercial banks should adhere to the Basel III accord requirements that advocates for buffer capital of $2.5 \%$. This could help to cushion the banks in case of a financial crisis. The study in addition recommends that commercial banks should adhere to the Banking Amendment Act (2012) that advocates for increase of minimum core capital to five billion Kenya shillings from one billion Kenya shillings to boost the financial stability of commercial banks in Kenya. Thirdly the study recommends that commercial banks whose going concerns are at stake should adopt the economies of scope. Here, two commercial banks that share the same market clientele can come together in form of mergers and acquisition. This would boost their synergy in terms of profitability, translating into financial stability of the banking sector in Kenya at large. Fourthly the study recommends that since the loans granted to insider results to huge loss hence the commercial banks should set limits on loans to insiders, including large shareholders, and related companies should be established. These limits should not only limit the amount of credit extended but should also require that the terms and conditions of such credits not be on more favorable terms than credit extended to similarly situated outside borrowers. In addition the study recommends that credit to one borrower or corporations should not exceed $15 \%$ or $20 \%$ of capital as practiced in developed counties. Furthermore the study recommends that fragile commercial banks should merge as a way to establish a stable commercial banking sector in Kenya this could assist towards achieving the Vision 2030 that advocates for well-functioning, efficient and stable financial system.

\subsection{Suggestions for Future Research}

From the findings, bank liquidity as a firm characteristic turned out to be statistically insignificant on financial stability of commercial banks in Kenya. However, a number of studies cited in literature review indicated that bank liquidity has a significant effect on financial stability. This turns out to be a contradiction from the research findings hence can be termed as a research gap. Furthermore the study has only concentrated on Camel Variables as firm characteristics. Researchers can also further this research through looking into other firm characterises 
which the study has not dealt with.

\section{References}

Adenutsi, E. D. (2014). Financial liberalization and international remittances in Sub-Saharan Africa: A panel data analysis. PhD thesis Stellenbosch University.

Ahmad, N., \& Mazlan, N. F. (2015). Banking fragility sector index and determinants: A comparison between local-based and foreign-based Commercial Banks in Malaysia. International Journal of Business and Administrative Studies, 1(1), 5-17.

Akram, T. Bilal, M. Asif, S., \& Ammar A, G. (2013). Influence of Bank Specific and Macroeconomic Factors on Profitability of Commercial Banks: A Case Study of Pakistan. Research Journal of Finance and Accounting, 7 (5), 100-115.

Ahmad, N., \& Mazlan, N. F. (2015). Banking fragility sector index and determinants: A comparison between local-based and foreign-based Commercial Banks in Malaysia. International Journal of Business and Administrative Studies, 1(1), 5-17.

Alber, N. (2016). Banking Efficiency and Financial Stability: Which Causes Which? A Panel Analysis. Paper was presented in the International Conference on Applied Economics (ICOAE 2016). Available at SSRN: https://ssrn.com/abstract=2846683.

Albulescu, T. C, (2015) Banks Profitability and Financial Soundness Indicators: A Macro-Level Investigation in Emerging Countries Procedia Economics and Finance 23 (6) (203 - 209.

Ali, M., \& Chin, H. P. (2018). The internal determinants of bank profitability and stability: An insight from banking sector of Pakistan. Management Research Review, 10, (7) 81-90.

Ameni, G., Chaibi, H., \& Omri, M A, (2017). The effects of liquidity risk and credit risk on bank stability: Evidence from the MENA region. Borsa Istanbul Review, 17, (4), 238-248.

Arellano, M., \& Bover, O. (1995). Another look at the instrumental variable estimation of error-components models. Journal of Econometrics 68 (12) 29-51.

Baltagi, B.H. (2005) Econometric Analysis of Panel Data. 3rd Edition, John Wiley \& Sons Inc., New York.

Baral, K. J. (2005). Health Check-up of Commercial Banks in the Framework of CAMEL: A Case Study of Joint Venture Banks in Nepal. The Journal of Nepalese Business Studies 2 (1) 41-45.

Basel Committee on Banking Supervision, (2012). A framework for dealing with domestic systemically important banks. Banks for international settlements.

Blundell, R., \& Bond, S. (1998). Initial conditions and moment restrictions in dynamic panel data models. Journal of Econometrics 8, (7), 15-43.

Brauers, W. K. M., Ginevičius, R., \& Podviezko, A (2014) Development of a Methodology of Evaluation of Financial Stability of Commercial Banks PANOECONOMICUS, 3 (10) 349-367.

Central Bank of Kenya. (2016). Bank Supervision Annual Report. Nairobi, Kenya.

Cytonn, (2018). Banking Sector Reports.

Dayong, Z., Jing, C., David, G., Dickinson, B., \& Kutan, M. A. (2016). Non-performing loans, moral hazard and regulation of the Chinese commercial banking system. Journal of Banking \& Finance , 6, (3), 48-60.

Dickson, P., \& Marobhe, M. (2013). The Influence of Capital Adequacy on Asset Quality Position of Banks in Tanzania. International Journal of Economics and Finance; 5,( 2),79-83.

Dovhal, S, Y., \& Chamara, O. R, (2015) Essence Of Financial Stability Of Commercial Bank and Effective Way Of Ensuring It. Financial Space 1 (17) 135-136.

Field, P. (2009). Discovering Statistics Using SPSS, second edition London; sage.

Fiordelisi, F., Marques-Ibanez. D., \& Molyneux, P. (2010). Efficiency and risk in European banking. Macro prudential Research Network, Working Paper Series, 1211.

Gathaiya, N, R (2017). Analysis of Issues Affecting Collapsed Banks in Kenya From Year 2015 to 2016. International Journal of Management and Business Studies. 7, (3) 9-15.

Githinji, E. (2016). Determinants of Financial Stability Among Commercial Banks In Kenya unpublished thesis, United States International University - Africa.

Greene, W.H. (2008). Econometric Analysis (6th ed.). Upper Saddle River, N.J.:Prentice Hall

Gudmundsson, R., Ngoka-Kisinguh, K., \& Odongo, M. T. (2013). The Role of Capital Requirements on Bank Competition and Stability: The Case of the Kenyan Banking Industry. Kenya Bankers Association-KBA Centre for Research on Financial Markets and Policy Working Paper Series.

Gujarati, D.N. (2003) Basic Econometrics. 4th Edition, McGraw-Hill, New York.

Gulzara, T., \& Hongxing, Y., \& Muhammad, H. (2018). Profitability Determinants of Financial Institutions: Evidence from Banks in Pakistan. International journal of Financial Studies., 6, (53), 90-95.

Helal, U., \& Dulal Miah, M. (2017). Efficiency and stability: A comparative study between islamic and conventional bank sin GCC countries. Future Business Journal 3,(6) 172-185.

Hussein, K. (2010) Bank-level stability factors and consumer confidence - A comparative study of Islamic and 
conventional banks' product mix. Journal of Financial Services Marketing. 15, (3) 259-270.

Kalunda, E. N. (2015). Financial inclusion, bank stability, bank ownership and financial performance of commercial banks in Kenya. Dissertation presented for the degree of Doctor of Philosophy in Accounting and Finance Department at University of Nairobi.

Kibritcioglu, A. (2002). Excessive Risk-Taking, Banking Sector Fragility, and Banking Crises. University of Illinois at Urbana-Champaign.

Kalani, V. M., \& Waweru, N.M. (2009). Commercial Banking Crises in Kenya: Causes and Remedies. African Journal of Accounting, Economics, Finance and Banking Research 5(6) 89-95.

Kandiru, E. M., Gachunga, H., Muturi, W., \& Ogutu, M. (2015). Influence of Firm Characteristics on the Impact of Disclosure and Transparency in the Performance of Companies Listed in Nairobi Securities Exchange. International Journal of Scientific Research and Management 4 (9) 67-71.

Karugu, C., Achoki, G., \& Kiriri, P. (2018) Capital Adequacy Ratios as Predictors of Financial Distress in Kenyan Commercial Banks. Journal of Financial Risk Management, 7, 278-289.

Kouser, R., Aamir, M., Mehvish, H., \& Azeem, M. (2011). CAMEL analysis for Islamic and conventional banks: Comparative study from Pakistan. Economics and Finance Review, 1 (10), 55-64.

Loloh, F. W. (2014). Measuring Banking Sector Fragility for an Early Warning System in Ghana Article in SSRN Electronic Journal.

Mariusz, P., \& Katarzyna, W. (2015). The impact of macroeconomic performance on the matters most? Research in International Business and Finance 3, (8), 69-82.

Mohamed, A., Abdessamad, S., \& Firano, Z. (2012). Financial Stability: Definitions, Theoretical Foundations and Roles of the Central Banks. International Research Journal of Finance and Economics, 7, (2), 78-85.

Mohd Zaini, A. K., Sok-Gee, C., \& Sallahudin, H. (2010). Bank efficiency and non-performing loans: evidence from Malaysia and Singapore. prague economic papers.

Ngaira, A. P., \& Miroga, J. (2018). Determinants of Financial Stability of Listed Commercial Banks in Kenya. The Strategic Journal of Business \& Change Management. 5 (4) 1074-1097.

Oduora, J., Ngokab, K., \& Odongoba, M. (2017). Capital requirement and stability in Africa. Research Department, African Development Bank, Cote d'Ivoireb Research Department, Central Bank of Kenya (CBK), Kenya. Review of Development Finance, 7, 45-51.

Olweny, T., \& Shipho, T. M. (2011). Effects of banking sectoral factors on the profitability of commercial banks in Kenya. Economics and Finance Review, 1(5), 1-30.

Sopan, j., \& Dutta, A. (2018) Asset Quality and liquidity Risk in Indian Banks: A Panel Data Analysis. Asian Journal of Research in Banking and Finance. 8, (6), 47-59.

Syajarul, I. M., \& Shifa, M. (2018). Cost Efficiency and Liquidity Risk in Banking: New Evidence from OIC Countries. International Journal of Business and Management Science, 8(2), 255-276.

Yong, T. (2016). Stability and profitability in the Chinese banking Industry: evidence from an auto-regressivedistributed linear specification. Investment Management and Financial Innovations 6(3), 89-98. 